\title{
Toys between the Ludic and the Pedagogical Perspective in Late 19th Century Romania'
} Cătălina MIHALACHE

\begin{abstract}
The paper proposes to identify what the $19^{\text {th }}$ century brought as novelties in the "life" of toys, seen as items dedicated explicitly to children; I have focused, naturally, on the Romanian case. By correlating the accounts to which I had access, I was able to outline certain evolutions in the manufacture, use, purchase, and characteristics ascribed to toys in that period. I have noted, first of all, the social differentiation in terms of toy consumption. The lower classes - defined by their views of childhood, material resources and well-delimited systems of gratification/rewarding - used more or less the same games and toys. Wealthier classes recorded a more diversified consumption, with urban influences, while the children of the elites became increasingly familiar with the offers of the Western world, brought directly from the source or just copied here. Another highlighted aspect is the increase in standardisation and even the industrialisation of toy production. The "merchandise-toy" no longer followed the logic of uniqueness, of perishable character, and functionalities predicted by children, for their personal use. Indeed, such toys had to play by the market rules set by adults, thus leading to imitation and to a more rigid toy than the "authentic" one, which was spontaneous and personalised. Such toys have messages, restrictions, and deformations that are highly relevant for the evolution of the relationships between adults and children. A third observation is that the school establishments and the pedagogical ethos of the time left their mark. "Educational" toys were not innocent, because they aimed to speed up the maturation of children, to enable them to develop academic and professional skills, limiting a child's freedom concerning the use of toys. The ideas of pre- and para-school education that used such items were adopted mainly by the "upper class" families, but they also acquired the direct support of the state, through the teaching institutions that the state controlled.
\end{abstract}

Keywords: childhood material culture, educational practices, social consuming, industrialisation, nationalism, traditionalism.

What does the second half of the $19^{\text {th }}$ century bring as a novelty in the "life" of toys as items dedicated explicitly to children within the Romanian Principalities? Upon correlating the accounts that I was able to access, interesting

1 This article elaborates on the paper presented at the international workshop At the Crossroads of Empires. Children and Consumption in 19th Century Central and Eastern Europe, July 11-12, 2019, New Europe College-Institute for Advanced Study, Bucharest. The paper was translated by Alina Veronica Piftor. 
evolutions may be highlighted regarding the production, usage, purchase, and features ascribed to toys during that period. Novelties may be proven, in variable proportions, but they do not exclude very long-term continuities, namely at least a century before and after the interval I will focus on (the last decades of the $19^{\text {th }}$ century and the first years after 1900).

The historical sources that I have used have focused on memories of children doubled by incursions into pedagogical publications and into the periodicals of the time.

From the beginning, it is worth showing the distribution of biographic information, quasi-non-existing for the early $19^{\text {th }}$ century and rather frequent (but not necessarily consistent) towards the end of the century. The authors of these accounts were mostly men, insisting upon showing their public merits, not their personal experiences, often failing to mention their first years of life. The typical construction of such an account passes from the ancestors directly to the first years of systematic education, opposed on principle to the idea of childhood and freedom (and play). As very early examples, I note the works of Prince Nicolae Suțu or the boyar Theodor Vârnav.

Fiction literature (see the short stories in "Amicul Copiilor"; for instance, Fetița nedreptățită, published in issue 4 of July 1893, focusing on the fate of a doll) or the memoirs considered genuine literary works have much more consistent references to the life of children in those times. There are precedents set in the classical literary works, which depict the exemplary world of toys in the Western and the Central-European world - such as The Nutcracker (a fairy tale published by E.T.A. Hoffman in 1816, which was a source of inspiration for the ballet of Pyotr Ilyich Tchaikovsky in 1892), The Steadfast Tin Soldier (published by Hans Christian Andersen in 1838), Pinocchio (published by Carlo Goldoni in 1883), Peter Pan (published by the Scottish writer J.M. Barrie in 1904).

It is no wonder that the pages signed by memorialists with real literary talent, such as Vasile Alecsandri, George Sion, Ion Creangă, Radu Rosetti are more careful concerning such details. There is a visible gender differentiation, explicable through the very structures of activity and education, different from one case to another. Clearly, women remember more often something about their toys or those of others than men do (their memories focus on expansive, physical and competitive games). Another peculiarity of the memoirists' sample refers to the social status of the authors (most likely similar to that of the readers for whom the texts were intended). The authors were educated people, who belonged to the upper classes or were, at least, materially well-endowed by the standards of that time. Their works do not lack references to "ordinary people," peasants, servants, or even the descendants of former gipsy slaves, but 
the distribution of "voices" is dominated by representatives of social elites and their perspective on the world.

Even the portraits of the time could suggest the same reluctant attitude in depicting children together with their toys. For example, in the first half of the $19^{\text {th }}$-century collection of such pieces, only one in 14 portraits are explicitly showing the two children of a family holding toys in their $\mathrm{arms}^{2}$. As a conclusion regarding the main historical sources from our collection, it a fact that may seem surprising (at least for a $20^{\text {th }}$-century or $21^{\text {st }}$-century reader) is worth noting: the scarcity of toy mentions in the memoirs available. Interesting parallelism with the situation in Germany can suggest a credible explanation: in 1900, only $20-25 \%$ of the children are estimated to have received toys "purchased", while memoirs only mention them vaguely, when they do at all ${ }^{3}$.

Regarding the second category of sources invoked, the texts with a pedagogical purpose that make direct references to games and toys, we can identify, first of all, a time gap of several decades compared to their western counterparts, but also a delay regarding the formulation of some opinions that tried to adapt the proposed theories to the local realities. The educational stakes of the toys are discussed late in the Romanian space, following the logic of a gap of several decades concerning the development of kindergartens and the corresponding pedagogy, proposed by Friederich Fröbel. Practically, the last two decades of the $19^{\text {th }}$ century also bring in Romania conscious visibility of the topic.

The third document category used refers to the press of the time, which in turn has a serious gap compared to most of Romania's neighbouring regions, not only chronologically, but also in terms of consistency, dissemination, professionalism of the journalists, etc. The periodical press of the time often features advertisements for new products and nominated those who assumed their distribution. Toy advertisements are not explicit (which, as I will show later, is caused by the structure of distributions networks), and they are difficult to identify until the 1880 s and 1890 s.

In the Bucharest Yearbook for [the year] 1885, for example, we find a special mention for "Jucărieri” [Eng., “Toys Merchants”], translated into French as

2 Mariana Vida, Elena Olariu, Marina Vazaca, Victoria Gheorghiță, eds., Epoca Biedermeier în Țările Române, 1815-1859 (Bucharest: Editura Muzeului Național de Artă a României, 2014), 139, figure 151.

3 David D. Hamlin, Work and Play. The Production and Consumption of Toys in Germany, 18701914 (Michigan: The University of Michigan Press, 2007), 57. This is a complex reality, which means we should pay more attention to the numerical/quantitative equivalents of real processes, with the transformations associated to modernisation, to "mass" consumption and culture, etc. 
Marchands de Jouets ${ }^{4}$. Three names of merchants are given: Kornstein, Santa Maria, and Ventzel. In a few years, we find three more mentions, but with some modifications. Probably the first person is the same, but the name is written a little differently (Hornstein), and an initial is specified (A.). Santa Maria is still present, but at a different address (from Episcopiei Street, the store moves to [Calea] Victoriei, in the heart of the Bucharest promenade. However, the next year we find the old address, from Episcopiei Street. Instead of Ventzel we find the merchant Steinberg, on the same Carol I central boulevard, but No. 3 is changed to No. 6. Hornstein was also residing on the same Carol I boulevard, at almost the same number (he appears first at 36, then at 37). In a few years, we find their names in roughly the same locations, which suggests that we are dealing with luxury goods and their professional salesmen. However, it was a problematic trade. The yearbooks from 1904 or 1910 no longer make any explicit references to toy sellers.

By way of comparison, we should emphasize that in Germany, for instance, soon after 1900, periodicals were featured that were dedicated to toy manufacturers 5 .

\section{The "worlds" of childhood, in the life of adults}

It is well known that childhood memoirs, in the Romanian case, have a classical reference in the pages written by the popular narrator Ion Creangă (born in 1837, deceased in 1889). These pages have long been included in the national literary and artistic canon, but they have not been much assessed in terms of valid historical documents, though the author's intention was precisely to reconstruct significant autobiographic episodes. Published in the years 18811882 , they remained for posterity as an exemplary description of the typical/ ideal/ happy childhood - still invoked as an immutable reference, over a century and a half later 6 .

4 See Bucharest Yearbook for [the year] 1885, 162, http://digitool.bibmet.ro:1801/view/action/ singleViewer.do?dvs=1610521686745 347\&locale=ro_RO\&VIEWER_URL=/view/action/ singleViewer.do?\&DELIVERY_RULE_ID=10\&search_terms=anuarul $\% 20$ bucure\%C5\%9F tilor\&adjacency $=\mathrm{N} \&$ application $=\mathrm{DIGITOOL}-3 \&$ frameI $d=1 \&$ usePid $1=$ true \&usePid $2=$ true, accessed on 13.01, 2021.

5 Hamlin, Work and Play, 2-3.

6 There is a topos of representations of childhood (though the language was dialectal and archaising, and the realities described are less and less intelligible for the future generations), which has started losing consistency in the past few decades, given the technological revolution and the demographic movements that modified dramatically the profile of the "traditional" Romanian village (more than the political changes of the last century). Even given the lack of references to Creangă's works, one can find accounts of happy childhoods, in the 
However, Creangă's childhood does not mention toys in their modern meaning: specially designed items made by adults or under their supervision (and even sold) for children's entertainment ${ }^{7}$. This prompts me to agree that such toys could have very well not existed ${ }^{8}$, for it is well known that children can play under almost any circumstances, using any resources, being mainly interested in imitating or parodying the life of adults.

However, in the framework of that mostly rural, premodern, traditional life, at any fair, children found sweet snacks, many times under attractive shapes, such as animals, small houses, hearts, etc. (made of sugar or sweet dough) which made them somewhat similar to toys - along with other basic entertainment means (such as swings /wheels/ "cabinets"). We can glean this not only from Creangăs Memoirs, but also from other testimonies. We can refer to Zoe Cămărăşescu's work, for a picturesque and detailed description of the traditional "fairgrounds of Moşi” [Rom., „bâlci de Moşi”] in Bucharest," or we can use a report with autobiographical inflexions from the middle of the twentieth century, but with references going back to the First World War, signed by Miron Radu Paraschivescu (born 1911). ${ }^{10}$ There were, however, items that were specially designed for delighting children and for play. I refer here to small coloured clay or wooden figurines, usually depicting animals or decorated with all sorts of ornaments, capable (or not) to issue all kinds of notable sounds or to produce other effects, such as motion effects, albeit rather rudimentary.

countryside, without any "bought" toys, even in the mid-20 $0^{\text {th }}$ century; children made their own toys, using anything they could find. Mariana Codruț, "Portret de copilărie," in Dan Lungu, Amelia Gheorghiță, eds., Cartea copilăriilor (Iaşi: Polirom, 2016), 52-56. It does not mean children did not know of their existence or that they did not want them.

7 Moreover, in a famous introductory paragraph, where he talks about "games and delights full of childlike fun and charm", the witty commenter states that the meaning ascribed here to the word jucării is pranks (antics); see Ion Creangă, Amintiri din copilărie, preface and notes by G.I. Tohăneanu and I. Funeriu (Bucharest: Editura Minerva, 1970), 36, note 1.

8 Hamlin, Work and Play, 16. More precisely, the author starts from the idea that toys do not satisfy a "natural human need". They do not meet any imperative need, for play - which is such a necessity, not only for children, but also for adults - can very well be conducted independently of the existence of specialised artefacts.

9 Zoe Cămărășescu, Amintiri, preface by Dan C. Mihăilescu (București: Casa Editorială Ponte, 2011), 162-164.

${ }^{10}$ He describes the attractions for children at the fairs in Râureni, as he found them in 1954, comparing them with the memories of his own childhood and with the stories of the elders about how it was at the beginning of the 20th century, and even earlier. See Miron Radu Paraschivescu, Bâlci la Râureni (Bucharest: Tineretului Press, 1964),.39-40, 52-53. For a broader history of the phenomenon, see: Ion Faiter, Trecător prin târguri și iarmaroace (Bucharest: Sport-Turism Publishing House, 1982). 
They are still present at traditional artisans, such as the famous whistling birds. They were accompanied by real miniature musical instruments, to be used by children and adults alike. For example, a well-known opera singer (born in 1881, in Ploieşti, to a family of clerks) discovered her musical talent during her childhood, when her grandfather brought her from a fair a modest clay instrument (ocarină). It was not meant for the high-end music or the educated population; it was trivial, cheap and probably perishable, with limited possibilities of expression, but it was considered a proper gift for a child who was already interested in music. A "real violin" followed shortly, because the grandfather, who was the caregiver, believed in her musical skills. She passed from the ocarină to the violin directly, without any teacher and before starting school, which bestowed upon the item a special quality, related to passion and freedom, and less to study or adult-supervised regulations ${ }^{11}$.

Such fair toys have been manufactured and sold throughout large areas within the East-European space, in the former Ottoman and Russian empires, with rather the same mechanisms, materials and outlets. The toy collections in Russia ${ }^{12}$ and Turkey ${ }^{13}$ feature impressive arrays, with regional specifics, endowed with amazing inventiveness, colours, simplicity of mechanisms and longevity of the products. It may thus be assumed that they had a common, premodern, mostly rural and artisanal background, specific to the civilisations that have intertwined in the Balkan area (without being borrowed or copied integrally and in an undifferentiated manner). They have been considered fair toys.

${ }^{11}$ Elena Drăgulinescu-Stinghe, Amintiri (Bucharest: Editura Muzicală a Uniunii Compozitorilor din Republica Socialistă România, 1965), 22.

${ }^{12}$ Short descriptions of such toys are accessible and consistent enough; see, for instance Ecaterina Makarova, Traditional Wooden Toys, published on https://www.kubidubi.com/article_03. html, accessed on January 12, 2021. It seems that what we call today the traditional Russian doll, the "Matryoshka," was inspired by Japanese items (which would have imitated a model from China), and then it reached Russia in the 1890s. See, for example, Solenn Cordroc'h, Russian Dolls: Originally from Japan, published on 19.04.2020, https://pen-online.com/culture/russian-dolls-originally-from-japan/, accessed on 12.01.2021.

${ }^{13}$ Concerning Turkey, the idea of traditional toys seems to be partially defined in direct opposition to imported or Western-like toys. The chronological references are less clear, but the inventory of the items that are part of the "traditional" heritage (in the sense of authentic, national, representative for the "genius loci") is more comprehensive. In terms of frequency, the toys (even with the mention "folklore dolls"), the wheeled items and the strategy games seem to dominate. See, for instance, the collection of over 800 items gathered from Anatolia, described at http://www.turkishculture.org/lifestyles/turkish-culture-portal/anatolianchildren/traditional-anatolian-697.htm, accessed on 24.06.2019 
The fair is by definition a space destined for exchanges and mixing, even from a social and cultural perspective. Situated at the limit between the urban and the rural, these spaces were dominated by villagers and by the "lower classes", but they did not rule out the occasional attendance of representatives of local/national elites. In certain cases, the "opening" of the event was attended by the royal family itself, who admired wholeheartedly the supply of the small rural and artisanal producers. In the late $19^{\text {th }}$ century, they constantly attended the famous "Târgul de Moşì" in Bucharest, where the children of the Crown Prince and his wife (Ferdinand and Maria) were rather amused ${ }^{14}$.

The public usually came for the show of products and services. This was no regular market where merchandises were exhibited. It was a leisure event associated with material benefits, (often correlated with public holidays featured in the religious calendar). Success was ensured by the capacity to attract, charm, persuade, to convince the customer to spend with pleasure, mostly given that the amounts to spend were not tremendous. On the contrary, such fairs were defined by their accessibility. In this context, the purchase of merchandise toys is also justified, regardless of how perishable or "primitive" they may have been.

But the precious artefacts of Western origin and appearance could not find their place there. Furthermore, the very idea of buying children's toys "from the fair" (in the sense of occasional market or small town nearby) was not commonplace among lower classes (i.e., most families). Exceptions thereof are late, rare and notable. I mention, as an example, the account of a graduate of the Theological Seminary in Chişinău, born in 1881 in the village of Trebujeni, the district of Orhei (part of the Russian Empire at that time). He was born to a family of wealthy and intelligent villagers. But, beyond the habits of the neighbours, the author highlighted with visible admiration that his father had promised him a violin early on - when he was old enough to understand their utility - "real toys from the fair". Actually, "no journey to Chişinău or Orhei ended without him bringing me a toy or a gift", even books ${ }^{15}$. I underline here the use of the word gift - unfamiliar to the rural traditional lexicon - which is a retroactive projection of the author, as well as the distinct use of the word toys. Gifts could mean something else, too.

Buying and offering toys could not be taken for granted, mostly in a world that has preserved for centuries certain restrictive (and coercive) representations of children and of childhood, in general. The "discovery" of childhood

${ }^{14}$ Cămărășescu, Amintiri, 163.

${ }^{15}$ Ștefan Gh. Usinievici, Nostalgii basarabene. Mărturii autobiografice (Cluj-Napoca: Casa Cărții de Știință, 1996), 9. 
as a significant and complex emotional, cultural and formative reality not only (or mainly) biological was a long-term process, which differentiated the social groups and the pre-modern and early modern lifestyles ${ }^{16}$.

Only in the mid- $19^{\text {th }}$ century, we can trace approaches that we may call normal today: a child seen as a valuable (material and affective) investment for the entire family; childhood perceived as a "privileged moment of existence"; a child seen as "a person" ${ }^{17}$. Such perceptions led to an entire array of representations, institutions and industries of childhood. However, they have occupied in a gradual and differentiated manner various geographical and socio-cultural spaces, thus leaving enough space for reminiscences and inertias.

It is interesting to note that the more conservative approaches to childhood were not present only among the lower social classes, but also at the very peak of the premodern social hierarchy, the members of which had their peculiar practices and values for centuries. Here, the miniature copy of the adults was followed literally, and children were endowed with all accessories of respectability: jewellery, weapons, pets/prestige pets, expensive attires, amazing personal items or souvenirs (such as trinkets or musical boxes), portraits, books, servants, available not only as playing companions but also as human toys.

A famous Romanian autobiographical short story of the $19^{\text {th }}$ century enthusiastically depicts such a socially inferior play companion (a servant at the boyar's court) but regarded with admiration, affection and respect by the child who was his master. I am talking here about the Romantic character Vasile Porojan, invoked in the memoirs of the writer Vasile Alecsandri, precisely for having witnessed long-gone times and customs, within the first decades of the $19^{\text {th }}$ century ${ }^{18}$. As for the "living toys," they were mostly Gipsy servants (slaves or recently freed from captivity), who were completely at the disposal of their masters, including children. George Sion (born in 1822), while remembering his first years of childhood, when he could not move or speak, talked about four little servants (aged 10-12, "some of our Gypsy boys") who took him everywhere, even playing the role of draft animals, because he thought he was entitled to treat them as such ${ }^{19}$.

These are not the areas that fuelled the change in perception and practices associated with childhood. Instead, the modernity promoted by the educated

\footnotetext{
${ }^{16}$ Philippe Ariès, L'enfant et la vie familiale sous l'Ancien Régime (Paris: Plon, 1960).

${ }^{17}$ Philippe Ariès, Georges Duby, eds., Istoria vieții private de la Revoluția Franceză la Primul Război mondial, vol. VII (Bucharest: Meridiane, 1997), 139-141.

${ }^{18}$ Vasile Alecsandri, Proză. Amintiri. Povestiri romantice (Craiova: Scrisul românesc, 1939), 87-93.

${ }^{19}$ George Sion, Suvenire contimpurane (Iași: Polirom, 2016), 349-352.
} 
and wealthy urban inhabitants within the Western world played that role. Retrospectively simplifying the history of the studied phenomena, we can say that, in the Romanian case, the Central-European middle class/bourgeois ideology was borrowed as a discursive and educational model mostly by the aristocracy and by those willing to improve their social status by investing in their children, and less through its direct adoption by the "regular" urban inhabitants. More precisely, it was the less wealthy strata of the aristocracy who took over the bourgeois model of education, not necessarily the townspeople themselves. This model included much more rigorous and stringent moral, professional and cultural training requirements than in the case of the noble lifestyle. Since the young offspring had to secure a future career, they could not rely (only) on family resources.

This new discourse of family values, of the need to demonstrate at the same time affection and respect for the individuality and the wishes of children correlated with the expectations projected on them by adults - was materialised in a new world of toys ${ }^{20}$.

\section{From fair toys to the toy market}

The non-temporal, ignored and perishable world of toys manufactured spontaneously by the children themselves or at their express request, anyway, was accompanied - at least in the period studied here - by a certain artisanal supply. It was rather specialised, stable in terms of form and content, accessible concerning the materials and costs, definitely attractive for most of the population, but accessed only occasionally.

However, in the last decades of the $19^{\text {th }}$ century, the progress of technology and industrialisation penetrated massively the world of toys, too. It seems that the German space recorded the most comprehensive expansion of the toy industry, in terms of quantity and concerning the variety of products, of the most popular types and technology innovation ${ }^{21}$. Both the German and the Austrian

${ }^{20}$ This is the main research hypothesis in the work of David D. Hamlin.

${ }^{21}$ The few exclusive areas for the toy industry (Nuremberg, specialised in mechanical toys; Sonnenberg, mainly manufacturing dolls; Erzgebirge, considered the region of traditional wooden toys for the German culture) developed in various ways, but at an incredible pace. The exports of German toys to the world grew considerably, too, though several other Western countries had remarkable production rates in this field. The figures seem unlikely but they certainly do not include all realities of the time. For instance, between the decades 1860 1880, the toy exports to America grew by over $600 \%$, only for the Sonnenberg region (Hamlin, Work and Play, 87). And this area was an artisanal manufacturing area, not industrialised like the one of Nuremberg. Here, the production of toy models featuring steam-powered engines grew from 495 models in 1875 , to 575,554 in 1888, while the production of "magical 
(Austro-Hungarian) Empires ${ }^{22}$ were major reference points of the toy markets in the Central- and East-European area, as they were concomitantly highly powerful and skilful cultural models, manufacturers and distributors.

Confirmation of this fact can be found, surprisingly, in many literary works. A character in the short stories of the memorialist Radu Rosetti (born in 1853) is capable of manufacturing amazing wooden toys, using just a pocket knife, skilfully; the miniatures were so great, that the child was amazed they were not coming to life. The reaction of the German master at the noble court sends us to the reference of the time: if he had been equally skilful, he could have founded a great toy factory in Vienna and he would have become rich ${ }^{23}$.

Naturally, the French experience in the delicate arts of trinkets, decorative items, fashion, intelligent and sophisticated artwork, led to remarkable outcomes in this field, too. In 1873, France obtained over 6 million francs, by exporting over 875 tons of toys ${ }^{24}$. But the big stores (such as Bon Marché or Galeries Lafayette), with renowned international subsidiaries, did not rule out imports, because in 1844 , for instance, they imported over 600,000 German dolls ${ }^{25}$. French nationalism intervened ever more acutely in this field, too, while the ban on imports during the First World War was preceded by genuine tirades denigrating the German dolls and exulting the beauty and qualities of local ones ${ }^{26}$.

How did these marvellous toys - still almost too good to be true and anyway very expensive for the vast majority of the Romanian families - end up in the hands of the lucky recipients? In 1867, Vasile Alecsandri sent from Paris to his 10-year-old daughter a wonderful doll that had charmed even him: her attire was high-end; she held a monkey; she could bend her knees, move her head and she was so convincing, that all she could not do was talk ${ }^{27}$.

The wealthy families received the catalogues of the most respectable distribution companies in Paris. Since November, children could pick exactly what they

flashlights" grew from 325,000 in 1891, to 400,000, in 1895 (Ibidem, p. 80). An equivalent of the Nuremberg area seems to have been Black Country in England, which produced large amounts of relatively cheap toys (Colin Heywood, O istorie a copiläriei. Copii în Occident, din Evul Mediu până în epoca modern (Bucharest: Editura Trei, 2017), 159.

${ }^{22}$ The Universal Exhibition in Vienna, in 1890, provided an ample overview of the international toy market, with the specificity of each important manufacturing country. Heywood, History of Childhood, 159.

${ }^{23}$ Radu Rosetti, Părintele Zosim și alte povestiri, edited by Radu Gârmacea (Bucharest: Humanitas, 2014), 7-8.

${ }^{24}$ Michel Manson, Jouets de toujours de l'Antiquité à la Révolution (Paris: Fayard, 2001), 323.

${ }^{25}$ Manson, Jouets de toujours, 324.

${ }^{26}$ Manson, Jouets de toujours, 324.

${ }^{27}$ Ioana Părvulescu, În intimitatea secolului 19 (Bucharest: Humanitas, 2005), 127. 
wanted for Christmas, while the cases labelled Grand Magasin du Printemps, Louvre or Bon Marché reached their destinations with all necessary precautions ${ }^{28}$.

Regarding the toys brought from France, it is perhaps useful to briefly present a short history of their sales in their country of origin. There is a careful description of the beginnings and evolution of toy selling in France, which shows that the first phase was one of mixing with other items, products made of similar materials, by artisans capable of providing them with a shape. Therefore, toys were first of all associated with the manufacturers of trinkets or with the artisans who worked with wood, glass, paper, cardboard, fabrics, metals (common or precious), etc. Their sale followed the same principle: distributors bought them from the artisans along with the other items produced in their workshops and they transported them on routes and towards outlets of which they were sure (such as seasonal fairs or pilgrimage itineraries). Like in any other business, the important aspects were individual skills, the capital of personal relations and the capacity of mobilising people, materials, deposits, forms of payment. The existence of guilds delayed significantly the specialisation of toy manufacturers who worked with composite materials and techniques. Their dissolution after the Revolution of 1789 gave a considerable impulse to toy production and distribution. Entrepreneurs emerged who were mainly interested in this field, followed by the great "houses" with a national and even international impact, in full expansion during the $19^{\text {th }}$ century. They took advantage of the technological evolution, of transportation getting cheaper, of advertising campaigns and of the new forms of promoting toys ${ }^{29}$. It may be assumed that, at least partially and with a delay of a few decades, this evolution may also be attested in the Central- and East-European space, the Romanian one included.

With or without access to toys, the children primarily enjoyed the affordable sweets. At least in urban areas, the ideal sweets of the exotic fruits - indispensable for children during the holidays, to make their joy complete - remained the undisputed monopole of Oriental traditions; they always came from certain areas of the Ottoman Empire.

Children back then were amazed by toys such as these: "real-size newborn twins, dressed in pink or blue satin, rocking horse, trains on rails, cooking set or complete tableware set for dolls, brightly coloured tin soldiers"30.

\footnotetext{
${ }^{28}$ Maria Cantacuzino-Enescu, Umbre și lumini. Amintirile unei prințese valahe (Oneşti: Aristarc, 2005), 60. The author was born in 1878, in the Rosetti-Tețcanu family, and she grew up at her family's estate in Moldavia. She also had a brother, so the presents had to satisfy both the girl and the boy's needs.

${ }^{29}$ See Manson, Jouets de toujours, 83-96; 179-194; 293-328.

${ }^{30}$ Manson, Jouets de toujours, p. 72.
} 
There were toy merchants and stores in the country, too, mostly in the big cities, selling them among other merchandises, more rarely in exclusivity. Such offers were not necessarily very impressive ${ }^{31}$ for everyone. Nonetheless, not all middlemen were bound to be successful in this market. Only the subsidiaries or collaborators of the great stores within the European capitals were able to persuade the public. This may also be deduced from an advertisement inviting the people in Bucharest to the reopening of the well-known Magasin Général de Paris, extended and renovated on Calea Victoriei, with a special department for toys, where they prepared "a highly varied array of novelties for children" 32 . These branches probably reduced the presence of the "toys merchants" mentioned in the years 1880-1890 (Hornstein, Steinberg, Santa Maria).

Romania may have also been a transit country for Western products towards other countries, located more or less far away. A Regulation for taxes concerning the merchandises that could enter Germany from Romania described highly accurately a great variety of toys; their complexity and the aforementioned materials mean they most likely came from other countries - renowned in the field - rather than Romania ${ }^{33}$.

Thus, there were multiple distribution routes. But why would the families buy such expensive items of prestige, on what occasions and to what use?

The engine of the modern toy market was the emblematic event of the new urban ideology of the family: Christmas ${ }^{34}$; not in its usual sense, as an (Orthodox) religious holiday, but as the exaltation of harmony, affection and constructive family ties. Santa Claus was not in the picture yet, but only its seemingly overwhelming symbol, the (Christmas) Tree. As it was like a giant toy ${ }^{35}$, decorated

${ }^{31}$ While trying to remember the merchandise of Madame Santa (most probably the already mentioned Santa Maria), the "toy merchant" with a store near Capşa (the most famous restaurant in Bucharest), Eliza Brătianu (born Ştirbey, in 1870) failed to identify something remarkable. She either went there rarely, or she would not buy toys for her, but for other children, or - as she noted angrily - "they must have been very ugly or unusable". Elisa Brătianu, Memorii (Bucharest: Editura Istoria Artei, 2015), 30-31.

32 "Epoca” (Bucharest), second series, year IV, nr. 934, of December 1 ${ }^{\text {st }}, 1898$, p.3. .

${ }^{33}$ See "Buletinul Camerei de Comerciu şi Industrie din Bucureşti”, nr. 5, January-March 1894, p. 313-314. One of the first local toy factories that I found out about (Teddy), of Botoşani, dates from rather late, namely from 1928.

${ }^{34}$ About the evolution of this phenomenon in the Germanic world and its influence on the toy market, see Hamlin, Work and Play, 28-37, 103-126. This new way of celebrating Christmas, different from the local traditions, gradually became the norm, starting from the educated elites who were receptive to the Western influences, and mostly from the Royal House of Romania, of Germanic origin, which gave a certain impulse to this phenomenon.

${ }^{35}$ In a moralising story of the time, there is a description of getting toys and ornaments from the Christmas tree, at the children's request. This was not the classical distribution of gifts 
with the shiniest ornaments, it was accompanied by certain rituals performed by adults or children, culminating with the show of gifts for the little ones. For many of the children of those times, it was the only occasion when they received gifts.

Eliza Brătianu stated clearly that "we only received toys on Christmas"36. Other authors are less categorical, but they undoubtedly associate the two notions: Matila Ghyka, born in $1881^{37}$; Sabina Cantacuzino (born in 1863), who mentions a certain distribution of gifts on Christmas and New Year's Eve ${ }^{38}$; Zoe Cămărăşescu (born in 1895), for whom Christmas meant, besides the tree and the household gifts, the direct participation in the shiny ceremonies of the Royal House and the multitude of spectacular gifts sent personally by Queen Elisabeta - for her mother, Zoe Bengescu, was the Queen's "lady-in-waiting”39, etc. She also mentions a wonderful doll received from the Queen on the day of Saint Zoe (December 18), thus on her name day ${ }^{40}$, but which happened to be around the winter holidays. The day indeed coincided with a family tragedy, and maybe the good Queen wanted to give the little girls further consolation (and she managed to do so).

There are also accounts of a different nature, about the forced festive character of Christmas, which may have become overwhelming for the children. Ana-Maria Callimachi (born in 1892), a representative of several branches of old and rich noble families, noted explicitly that (despite the gifts received) so many formal ceremonies ruined the joy of the moment and that since childhood she had "a strong sense of disgust for all Christmas nonsense"41. Other memoirs are even more precise in this respect. Maria (Maruca) Cantacuzino and her brother knew that they had to mimic as extravagantly as possible the surprise and joy of receiving gifts, "to struggle to shout their joy and to dance around the tree", to "exclaim loudly" - but still in a forced manner - "to throw

following the games and songs performed by children in front of the tree, the family and the potential guests. Each claimant got the favoured item on the spot, directly from the branches of the symbol-tree; hence, "they got one toy after another", including the golden star on the top. The modest child who asked for the simplest box was surprised to see, upon opening it, "a fairy jumping from it, on the back of a butterfly, even more beautiful [than her]". "Pomul de Crăciun”, Amicul Copiilor, no. 9 (December 1894), 263.

${ }^{36}$ Elisa Brătianu, Amintiri, 31.

${ }^{37}$ Matila Ghyka, Curcubeie, translated by Georgeta Filitti (Iaşi: Polirom, 2014 ), 34.

${ }^{38}$ Sabina Cantacuzino, Din viața familiei Ion C. Brătianu, 1821-1891, third edition, edited by Elisabeta Simion (Bucharest: Humanitas, 2013), 110-111.

${ }^{39}$ Cămărășescu, Amintiri, 36-37; 80-85.

${ }^{40}$ Cămărășescu, Amintiri, 26.

${ }^{41}$ Ana-Maria Callimachi, Lumea toată era a mea. Amintirile unei prințese, translated by Lidia Grădinaru, notes by Filip-Lucian Iorga (Bucharest: Editura Corint, 2015), 92. 
themselves in the arms of their parents" and other such things; "to persuade everyone of our great happiness, we hurried to open various packages, tied with red or purple ribbons, discovering what they contained with great enthusiasm". They were genuinely happy only when adults left the room and the children were finally alone, in silence, in front of the tree, even "with the candles blown off"42.

The precious gifts demonstrated the affection of adults for children, the virtues of the little ones, who deserved such gifts, the significant financial resources of the family, and not least, their capacity of keeping up with the habits of the time, of being up to date, regardless of the pretentious character of the actuality.

The "merchandise-toy" does not fit the logic of uniqueness, of perishability and of the functionalities preferred by the children, who play following their own needs and skills. Such toys must follow the rules of adult markets. The manufacturers, the sellers and the buyers impose to children their views on toys, thus imitating and "stiffening" spontaneous and personalised items.

These were toys with a message, with restrictions and alterations that are highly relevant for the ever more complex evolution of the relationships between adults and children.

\section{The formative missions ascribed by adults to toys}

Philosophers and pedagogues have ascribed, from time to time, educational virtues to toys, arguing that they can contribute to a better understanding of the world by the children, thus to their more rapid development and growing up. Comenius and mostly John Locke have insisted upon this topic ${ }^{43}$. Rousseau was more measured, as he gave priority to nature and to non-manufactured items ${ }^{44}$, which could target the undeveloped senses of children more effectively. From various directions (Empiricism, Enlightenment, Romanticism), impulses emerged gradually that argued for the utility of toys from the perspective of proper child-rearing. They were not coherent. For some, toys could have immediate practical applications ${ }^{45}$ (such as learning to read, to count or to memorize notions of geography or history). For others, they were valuable precisely because they suggested fantasies and very personal creations by children ${ }^{46}$, far

\footnotetext{
${ }^{42}$ Cantacuzino-Enescu, Umbre și lumini, 69-72.

${ }^{43}$ Manson, Jouets de toujours, p.137-154.

${ }^{44}$ Manson, Jouets de toujours, 212-215.

${ }^{45}$ Hamlin, Work and Play, 129. Locke, for instance, proposed to have letters printed on wooden surfaces, as an elementary assisting tool for learning to read.

${ }^{46}$ Hamlin, Work and Play, 134.
} 
from the immediate constraints of regular items and norms. Abstract ideas had a hard time reaching the concrete world of manufacturers, sellers or buyers of toys, however.

The one who coined the idea of the educational utility of toys was Friedrich Fröbel (1782-1852), the founder of "kindergartens", who started from the ideas of Johann Heinrich Pestalozzi (1746-1827), whose disciple he was. Maybe he would not have been so persuasive in his writings or activities, without the persistent intervention of the supporters and continuators of his ideas, led by the baroness Bertha von Marenholtz-Bülow ${ }^{47}$.

His views may seem contradictory. To him, the games/ play of children comprised extremely important activities, helping a child discover himself and the world. On the other hand, the most serious forms of learning should have assisted such efforts, under a likeable form and, at least apparently, without constraints, in an easy-going manner. None of the ideas was completely new, but the constant association of learning and the ludic was a revolution of pedagogical thought and practice. This idea was, maybe, too revolutionary to succeed (criticism was immediate and it continued long afterwards). Success was due to the targeting of young ages, especially pre-school children (another remarkable innovation) and mostly to the careful delimitation of innovations from the area of "classical" pupils (subjected from the start to the social rigours of adults) and of the conservative-elitist settings.

But what were the toys envisaged by Fröbel? They were not those cohorts of dolls, tin soldiers and likeable animals, regardless of their realistic appearance. He imagined a few sets of rather abstract items (that he called "gifts", not toys), to exemplify to children the main geometrical shapes existing around them (flat or volumetric). He proposed cognitive activities based on manipulating spheres, cylinders, and mostly cubes and wooden sticks, which could make up a multitude of buildings inspired by reality (houses, bridges, castles, etc. ${ }^{48}$.

He did not avoid completely the classical toys (the sphere could be a mere ball), as he relied on familiarity and attractiveness. Thus, people could end up in the same area of classical toys, but only if they were manipulated correctly, such manipulation being supervised by an adult, to produce the expected results. But the long-term effects proved to be divergent and unpredictable, exceeding Fröbel's calculations.

\footnotetext{
${ }^{47}$ Hamlin, Work and Play, 136-137.

${ }^{48}$ J.F. Jacobs, Manuel pratique des Jardins d'enfants de Frédéric Froebel, à l'usage des institutrices et des mères de famille, composé sur les documents allemands par J-F Jacobs. Avec une introduction de Madame la Baronne de Marrenholtz, fourth edition (Bruxelles: F. Classeu, Libraire-Éditeur, 1880), 45-100.
} 
On the one hand, these new educational objects encouraged a boom in the manufacturing of didactic materials for small children; the dominant ones were not abstract, as Fröbel had envisaged them, but rather reproduced important items and tools, plants, animals, landscapes, historical characters, etc. Though they were not included in the traditional sphere of toys, they sought to preserve something of the initial idea of turning learning into something more likeable. Moreover, children often found opportunities to alter and distort their sober, instructive goals, even by destroying them.

On the other hand, toy manufacturers developed in their own way the idea of the educational purpose of toys, thus proposing constructive-formative sets that had to develop qualities that children often lacked: patience, perseverance, desire to work, less agitation and annoying sounds for adults, a better understanding of the items surrounding them, etc. This led to the fashionable trend at least in the "high-end" society - of the cubes with or without images printed on them ${ }^{49}$, puzzles, stickers ${ }^{50}$, colouring or cutting sheets, sets of modelling/ copping saw, "panoramas", the idea of collecting and studying stamps, plants, minerals, etc (until then reserved mainly to adults). Or, more simply, the manufacturers and sellers came up with new promoting discourses for traditional

${ }^{49}$ Starting from the didactical idea of wooden cubes/ bricks to be put together temporarily and demonstratively in various ways, a toy manufacturer made a fortune and developed an entire industry, still functional today. I am referring here to Richter's Anker Steinbaukasten, which transformed the neutral pieces proposed by Fröbel, into a series of shapes and utilities with precisely and attractively finishing touches, with the building schedule included (to make a house, a castle, a bridge, a cathedral, etc.). See Hamlin, Work and Play, 55. They were a kind of a $19^{\text {th }}$-century Lego, and the idea started from Friederich Adolf Richter, a chemist and pharmacist (Ibidem, p. 106); they proved once again the importance of the impulse given by toy manufacturers, because the production of the pieces was a complex mixture of "quartz, chalk and flax seed oil", making their debut in 1882, in the German town of Rudolstadt. They reached their peak popularity in 1900. See Walter Benjamin, Copilărie berlineză la 1900. Ultima versiune şi fragmente din versiunile ulterioare, translated by Andrei Anastasescu (Bucharest, Humanitas, 2010, 150, note 6). Walter Benjamin was born in 1892, to a family of culturally assimilated Jews, part of the great German middle class. This does not necessarily mean that all children obediently followed the models proposed. On the contrary, some ignored deliberately "the instructions on the boxes" to make a certain image and they made "nonsensical" things using those pieces, as mentioned by an author born in 1892. Paul Vaillant-Couturiers, Copilărie. Amintiri din copilărie şi din tinerețe, translated by Aurel Tita (Bucharest: Editura Tineretului, 1964), 17.

${ }^{50}$ The term is German (Anziehbild) and it is related to the technique of printing decorations on ceramic items (dating to around 1780). It involved the transfer of an image from one material to another, by taking it off and printing it using heat, water, adhesive substances, etc. It became popular mostly in the $19^{\text {th }}$ century, for a mainly industrial purpose, before being directed towards children (https://de.wikipedia.org/wiki/Abziehbild, accessed on 7.07.2019). 
products, ascribing qualities that did not require any more proofs. The parents/ buyers were seduced by the idea of utility for education, and the toy industry extended massively in this direction ${ }^{51}$.

There had already been more or less explicit utilitarian presuppositions about toys, an equivalent of a pre-existing hidden curriculum. Parents offered to their children edifying toys, to help them acquire the social roles and values and the desirable models, in a seemingly non-restrictive but coercive manner, achieved by repetition, omissions, delimitations, practices that were more or less recommended ${ }^{52}$. The most obvious example is that of the dolls, closely followed by tin soldiers. But many professional exemplifications, models of household/ home, entire episodes of real life were endlessly reproduced, always repeating what families expected from their children. And their force of seduction was undeniable, thus being able to even determine the course of a life.

Zoe Cămărăşescu is one of the memoir authors who describes the most frequently and in most details the toys of her childhood. An honourable place is held by the "wonderful things" sent by the Queen herself, which were complex miniatures: reproductions of stalls with market merchandises, a stable, and a castle with its park (including a lake with "real" water gush), trousseaus and complex accessories for dolls, etc. But, as it would be expected, the most precious items were carefully guarded by the nanny, to prevent the children from destroying them! Anyway, the girls (they were four sisters) still believed their toys were diverse ("all kinds of toys") and highly complex, "things we could not even have dreamed of" ${ }^{33}$. This was part of the Christmas recipe: the surprise, the overwhelming effect of the beautiful and unique items received.

Going beyond the strictly defined boundaries of the Romanian cases, here is another relevant example. Upon narrating his childhood as a shy boy, far from the ideals of his famous family, Sir Winston Churchill (born in 1874) described how his comprehensive and elaborate collection of tin soldiers (he had 1,500 items!) persuaded his father to guide him towards a military career. The child was not a mere collector of nice things; he tried to copy and collect reliable information concerning the functioning of armies or the unfolding of military events $^{54}$. The choice proved to be inspired, Winston had notable successes as a military strategist, which were useful in his future political career, for which he is honoured in the gallery of the most important British political leaders.

\footnotetext{
${ }^{51}$ Hamlin, Work and Play, 143-146.

${ }^{52}$ Hamlin, Work and Play, 21-28.

${ }^{53}$ Zoe Cămărășescu, op.cit., p. 84.

${ }^{54}$ Winston Churchill, Anii tinereții mele, translated by Ana Irina Ionescu (Bucureşti: Editura Herlad, 2017), 35-36.
} 
However, it must also be noted that there has always been a certain distrust concerning toys from the part of the adults. The parents, specialised pedagogues, philosophers, artists or authorities of the time regularly issued warnings against offering toys per se, against the quantitative excess or against the children being left unattended for a long time, in the company of childish games. For this reason, parents were even more sensitive to the argument of "useful toys" 55 .

Sceptical philosophers and pedagogues were especially reluctant to use toys for educational purposes, since they seemed the exact opposite of what was required from children: disciplining, becoming mature quickly, being reasonable, accepting restrictions and prohibitions, reducing the forms of escapism, of fantasising, of a childish yet endangering consumerism, etc. ${ }^{56}$

Such objections may be found in the Romanian society, too, even in the recommendations for applying the educational method proposed by Fröbel. He founded the first kindergarten in 1837, but in the Romanian space, they emerged (sporadically) over two decades later. Their number and importance grew quite slowly in the subsequent years; only as late as $1880-1890$, they became a significant phenomenon ${ }^{57}$. State intervention acknowledged their existence definitively ${ }^{58}$, but also delimited their functioning, within the limits of clear public missions. According to the spirit of the times, it is worth pointing out, in the speech devoted to their inauguration, the civic-patriotic and nationalist, civilising, rationalising and disciplinarian drives that marked the entire educational system, under the patronage or supervision of the Romanian state.

Furthermore, one of the first works dedicated to the effective application of the "Froebelian" method in the country was published at the request of the minister of Public Education, Spiru Haret ${ }^{59}$. The work was published in 1900 and printed as late as in 1904, but it was based on the direct experience of the authors (the Neamțu spouses, both with degrees in pedagogical studies), who had opened their kindergarten as early as in 1890.

${ }^{55}$ Sabina Cantacuzino, the oldest daughter in the family of Ion C. Brătianu (who had eight children), authoritarian and extremely responsible by nature, highlighted in her memoirs that on holidays they received "beautiful and useful toys", for the purchase of which "parents made sacrifices” (an obviously retroactive and moralist appraisal); see Sabina Cantacuzino, Din viața familiei Ion C. Brătianu, 111.

${ }^{56}$ Hamlin, Work and Play, 165, 172-175.

${ }^{57}$ See, for a short history of kindergartens in Romania, Cătălina Mihalache, Copilărie, familie, şcoală: politici educaționale şi receptări sociale (Iaşi: Editura Universităţii “Al. I. Cuza”), 85-95.

${ }^{58}$ In 1896, a first Regulation for the functioning of kindergartens in Romania was finally issued.

59 The most praised minister of Romanian public education, with a great influence in the evolution of the national system of schooling, mainly from the 1890 s to the interwar period. 
All the well-known advice present within Western literature was carefully reproduced in their book. The authors added their wish to prove the necessity of the recommended practices in order to provide a more national, Romanian orientation to the education offered to kindergarten children. They referred mainly to the games, songs, poems and history or geography notions, but in their view, even didactic materials/educational toys could be made more Romanian. How? By replacing the abstract wooden geometrical shapes with local materials, familiar to the little ones, such as the pumpkin shell and seeds, the willow branches, "the corn stalks and stems" ${ }^{60}$. Such advice confirmed the general tendency to associate the nation with the rural virtues, to reinforce the local handicrafts and to rediscover the „authentic” esthetical traditions of the Romanian land, also apparent in other fields ${ }^{61}$.

Nationalism could also be associated with other political and cultural trends of the period. Ever since 1887, the opening of a kindergarten in Iaşi fuelled a storm in the pages of the socialist publication "Contemporanul", when powerful criticism was advanced concerning its non-Romanian profile and the fact that it was not accessible to lower classes ${ }^{62}$.

In those times, the toys and games of children were subjected to many influences: exalting progress through science, technology, industrialisation; militarism, imperialism, Eurocentrism, the offensive of the press and the proliferation of mass culture establishments, etc. ${ }^{63}$ They penetrated later and selectively the Romanian space, depending on the culturally dominant trends of the era ${ }^{64}$, but they were almost untraceable before 1900 .

Thus, it appears that toys were the favourite item of ... play for the adults, who insisted more or less imperatively on their options, which they viewed as belonging to their children. Children have always had, however, the freedom of deviating from the instructions of the adults, who were not able to supervise permanently the effective or only imaginary use of these

${ }^{60}$ Luisa I. Neamțu, Ion G. Neamțu, Metodul de educațiune a copiilor mici după sistemul lui Fröbel. Manual portativ pentru educatoarele de copii din școală și familie (Bucharest: F. Göebl, 1904), 50 .

${ }^{61}$ We dealt more extensively with this subject in Cătălina Mihalache, Școala și artizanatul (Cluj-Napoca: Editura Limes, 2007).

${ }^{62}$ Cătălina Mihalache, Copilărie, familie, școală..., 87-89.

${ }^{63}$ As proven by David D. Hamlin in almost his entire work.

${ }^{64}$ On the militarization of children's material culture around the period of World War I, see also Ramona Caramelea, „Imaginile războiului în „Revista copiilor și a tinerimei”, in Copilării trecute prin război. Povești de viață, politici sociale și reprezentări culturale în România anilor 1913-1923, eds. Cătălina Mihalache, Nicoleta Roman (Iași: Editura Universității „Alexandru Ioan Cuza”, 2020), 53-54. 
items ${ }^{65}$. Fortunately, the adults used to think their mission was completed once they purchased and delivered the toys to their direct "beneficiaries".

\section{Rezumat}

Articolul îşi propune să identifice ceea ce aduce nou secolul al XIX-lea în „viața” jucăriilor ca obiecte dedicate explicit copiilor insistând, fireşte, asupra cazului românesc. Corelând mărturiile la care am avut acces, putem contura anumite evoluții în producția, folosirea, achiziția, însuşirile atribuite jucăriilor vremii. Observăm, în primul rând, că se amplifică diferențerile sociale ale consumului de jucării. Clasele populare, definite prin concepții proprii asupra copilăriei, resurse materiale şi oportunități de gratificare/recompensare bine delimitate, vehiculează cam aceleaşi jocuri şi jucării, aparent atemporale (le putem regăsi şi în secolul următor). Clasele mai înstărite îşi contureză un consum mai diversificat, de influență urbană, pe când copiii elitelor cunosc tot mai amănunțit ofertele lumii occidentale, aduse direct de la sursă sau doar copiate aici. Un alt aspect, care iese în evidență, este cel al creşterii standardizării şi chiar al industrializării producției de jucării. „Jucăria-marfă” iese din logica unicităţii, a perisabilității şi a funcționalităților preconizate de copii, pentru uzul lor personal, intrând în regulile de piață ale adulților, care mimează şi ridigizează jucăria „autentică”, spontană şi personalizată. Sunt jucării cu mesaj, cu restricționări şi cu deformări foarte relevante pentru evoluția relațiilor între adulți şi copii. $\mathrm{O}$ a treia observație este aceea că instituţiile şcolare şi ethosul pedagogic al vremii şi-au imprimat, la rândul lor, propria amprentă. Jucăriile „educative” nu erau inocente, căci trebuiau să grăbească maturizarea copiilor, să le dezvolte abilități de uz şcolar şi profesional. Din start, ele porneau de la o concepție opusă libertății copilului în ceea ce priveşte folosirea jucăriilor. Ideile de educaţie pre- şi paraşcolară care apelau la astfel de obiecte au fost interiorizate, cu precădere, de familiile „burgheze”, dar au dobândit şi suportul direct al statului, prin instituțiile didactice pe care le controla.

Cuvinte-cheie: istoria copilăriei, ideal pedagogic, grădiniță, consum social, industrializare.

Cătălina Mihalache, "A.D. Xenopol” Institute of History of the Romanian Academy, Iaşi (Romania), Email: catalinamihalache@yahoo.com

${ }^{65}$ „Ca orice pasiune, jocul consta în a da în chip arbitrar un sens sau o valoare imaginare oricărui obiect [...] și a face apoi ca și cum acel sens ar fi atât de inerent obiectului, încât nu putem să i ne sustragem" ["Like any passion, the game consists in arbitrarily giving an imaginary meaning or value to any object $[. .$.$] and then pretending that this meaning is so inherent in$ the object that we cannot evade it."]. Nicholas Grimaldi, Tratat despre banalitate, translated by Dan Petrescu (Bucharest: Editura Nemira, 2006), 123. 